\title{
LAND COVER AND LAND USE CHANGE IN THE CENTRAL SPANISH-PORTUGUESE BORDER REGION
}

\author{
Francisco Javier Jaraíz Cabanillas \\ Julián Mora Aliseda \\ Departamento de Ciencias del Territorio. Universidad de Extremadura \\ jjaraiz@unex.es, jmora@unex.es \\ José Antonio Gutiérrez Gallego \\ Departamento de Expresión Gráfica. Universidad de Extremadura \\ jagutier@unex.es
}

\begin{abstract}
Socio-economic activities are the main causes of change in land cover and land use that determine the structure, function and dynamics of landscapes. Our main objective was to evaluate the repercussions and consequences of recent socio-demographic changes on the land cover and land use in the Raya Central Ibérica. We used data from the European Project CORINE and conducted multivariate analysis, information analysis and generalized linear models (GLM). GLM demonstrated its utility for identifying relations between independent variables and land cover/land use changes. The results of different analyses show that the changes have been insignificant in general terms, however, some municipalities have been marked by important variations in land cover and land uses such as irrigated land, agroforestry areas or sclerophyllous vegetation.
\end{abstract}

Keywords: border region, land cover and land use change, generalized linear model, driving forces.

\section{RESUMEN}

Los procesos socioeconómicos son la principal causa de los cambios de cobertura y uso del suelo. Nuestro principal objetivo fue evaluar las repercusiones y las consecuencias de

Fecha de recepción: marzo 2011.

Fecha de aceptación: julio 2011. 
los recientes cambios socio-económicos en la Raya Central Ibérica. Tanto la base de datos numérica como geográfica que empleamos, procede del Proyecto CORINE. Para el estudio de los cambios de cobertura y uso del suelo y los factores condicionantes empleamos modelos lineales generalizados (GLM). Los GLM demostraron su utilidad para la identificación de la relación existente entre las variables independientes y los cambios de cobertura y uso del suelo. Los resultados de los diferentes análisis demuestran que los cambios han sido insignificantes en términos generales, no obstante, existen variaciones importantes entre municipios en algunas coberturas y usos del suelo como los regadíos, las superficies agroforestales o la vegetación esclerófila.

Palabras clave: espacio transfronterizo, cambio de cobertura y uso del suelo, modelo lineal generalizado, factores causantes.

\section{INTRODUCTION}

We used GIS to study the environmental impact of recent economic activities on the border region of the Raya Central Ibérica (Spain-Portugal). Our principal objective was to evaluate the repercussions and consequences of recent socio-demographic changes on the land cover and land use of the area. This was accomplished by assessing land cover and land use change in the region from 1990 to 2000 . Specifically, this study addressed the effects of changes in demography, economy, agriculture, transportation, as well as particular features of the environment, on land cover and land use change, i.e. on urban, agricultural, and forest ecosystems and biological diversity. We used data from the European Program CORINE and conducted multivariate analysis, information analysis, cluster analysis, logistic regressions (generalized linear models), models of accessibility and maps of land cover and land use developed from satellite images ${ }^{1}$.

This study constitutes one the first applications of data from the European Program CORINE database and use of GIS methods to address land use land cover change in a large, rapidly changing border area. The approach enabled us to assess the effects of changes taking place in a transnational region.

For this project, we used data from the CORINE Land Cover 2000 (I\&CLC2000) Project to define land cover and land use and identify causes of change. The data layers used were CLC2000, land cover for the year 2000, and CLC90/2000-changes, land cover changes between the years 1990 and 2000. These cover the area of the European Union countries at a scale of 1:100 000 .

1 The land cover is a biophysical layer on the earth's surface and its immediate lower stratum that includes a certain amount, quality and distribution of natural resources. Originally, the term was used to describe biophysical attributes but now has expanded to cover human buildings and paved surfaces and structures. To address the latter aspect of the land cover, it is essential to link it with the concept of land use, i.e. the mode of administration of the biophysical attributes of the earth's surface. According to FAO: «Land use relates to the function or purpose for which the inhabiting people use the earth's surface and define human activities that directly relate to land, use of resources and the impact produced on them» (OSE, 2006). 
In summary, the aims of the research were to: 1) determine and explain the causes of land cover and land use changes in the Raya Central Ibérica between 1990 and 2000,2) ascertain the impacts of land cover/land use changes on natural resources and the environment in the study area, 3) optimize methods for interpreting land cover and land use change studies, and 4) generate thematic cartography of results.

\section{I.1. Literature review}

\section{I.1.1. Land use planning and economic development in rural regions}

Land use planning is a process during which different groups vie for control over the visions of landscape that guide the planning process. Land use planning is an important institutional endeavor that struggles to define the meaning of «natural environment» and describes how human communities interact with nature (Hillier, 1998). The land use planning process has been largely neglected by political ecologists.

Whatmore and Boucher (1993) addressed the narratives that govern the treatment of nature in planning. They state that land use planning formalizes the separation between nature and abstract space through the written codes of legal statutes and professional conduct, which impose a site-based, rather than system-based narrative structure on treatment of the environment.

The different land uses of rural regions directly raise the question about driving forces behind the diverse rural regions. Such a question is merely a variant of the often-posed question in economic literature: why do economic growth rates differ among regions? (Terluin, 2003).

Combining the notions of territorial, population and global dynamics (political, economic), we arrive at a view of rural restructuring (Bor et al., 1997). According to this view, rural development emerges from an interaction between global forces and local responses. Global forces originate from the globalization process, while local responses refer to the diversification of economic activities and adjustments to new conditions by local actors.

The debate on economic development in rural areas is concerned with how rural development policy can stimulate economic growth. Contributions to this debate mainly originate from geography, sociology, agricultural economy, demography, ecology, rural planning and administrative sciences (Cloke, 1997).

\section{I.1.2. Rural development in the Raya Central Ibérica}

In the Raya Central Ibérica, land use is dominated by the agrarian system, specifically an agro-silvo-pastoral system, which is a specific cultural landscape with high biological, scenic and recreational value. During recent decades, a combination of factors has led this system to change through intensification, extensification and land abandonment. A new landscape mosaic is evolving on a regional scale (Pinto-Correia, 2000).

Intensification and extensification in the last few decades has led to degradation of the agrarian system. Furthermore, socioeconomic and political transformations in the area of 
study led to increased agricultural wages. Coupled with migration from the countryside, this made it difficult to maintain low-cost manual shrub clearing and traditional management (Balabanian, 1984; Joffre et al., 1991).

Furthermore, changes in the spatial configuration of the landscape and rural abandonment have increased tensions among components of the social-ecological system. Recovery and sustainability of this system would be more viable under adaptive management schemes with active participation of the local population in the decision-taking process. The goals of such management should be maintaining the landscape with acceptable levels of biological diversity and productivity (Rescia et al., 2008). Interactions between humans and nature create cultural landscapes that reflect past and present day relationships between society and the environment (Brook and Bowman, 2006).

Increasing depopulation of the countryside, a phenomenon that is becoming more widespread in rural territories in the interior of Spain and Portugal, has very high socioeconomic and ecological costs. These include loss of ancestral cultures, deterioration of landscapes, loss of biodiversity and declines in economic profitability (Romero-Calcerrada and Perry, 2004). There is however, limited knowledge of recent changes in land uses or the driving forces and implications of such changes within the context of local development.

The principal problem in the study area is a decline in resilience of the social-ecological system. There is thus a need to prevent the abandonment of the rural environment. There is also a need to develop economically and environmentally viable alternatives, and to explore the future stability of the cultural landscape to guarantee its functionality (Rescia et al., 2008).

In order to find effective solutions for these problems, innovative ideas must emerge. The new ideas may lead to development of a new instrument, a common approach used by different sectors to manage rural landscapes. This new approach may involve combinations of different strategies and measures, including an agro-environmental program (Macfarlane, 1998).

\section{I.1.3. Models and scenarios of land cover and land use change}

Irwin and Geoghegan (2001) studied the theories, data and methods used to develop spatially explicit economic models of land use change. They propose that modeling the economic structural processes that underlie land use change has several benefits. First, by modeling human behavior directly, rather than the outcome of human behavior, the underlying spatial and temporal dynamic processes associated with the economy can be made explicit. This allows consideration of the cumulative effect of factors over time on an individual's land use decisions and of potential spatial interactions among economic agents. Second, and perhaps most important, issues of endogeneity can be addressed using a structural modeling approach. Such an approach is necessary to estimate parameters accurately and evaluate policy implications correctly.

Other authors, as Verburg et al. (2006), created scenarios of land use change to understand the dynamics of landscapes throughout the whole European territory. Their consideration of the entire EU region gave the work a global vision, perhaps the outstanding contribution of this work. 
A multitude of studies have addressed changes in land use and landscape in Europe. Only a few, however, as pointed out by Verburg et al. (2006), have covered all of Europe (Rounsevell et al., 2005). Others have investigated specific processes of land use change in local case studies (Hietel et al., 2004; Kristensen et al., 2004). Such local studies of landscape change often focus on cases in which land use change has led to severe environmental problems. Furthermore, most local studies focus on historical changes in landscape, but are not necessarily representative for large areas and do not provide information on the aggregate impact of these changes at the level of Europe as a whole. On the other hand, existing studies at the larger scale provide an overview of the main land use changes, but fail to integrate the different processes of change and are conducted at such coarse spatial and temporal scales that they cannot provide insight into the consequences of landscape changes.

There is thus a gap between European-level explorations of future land use changes and local case studies. This illustrates the need for downscaling approaches that link European-level developments to landscape-level impacts. Therefore, with respect to the work of Verburg et al. (2006), downscaling is required to capture the enormous variability of landscapes across Europe.

De Aranzábal et al. (2008) argue that the cultural landscape changes because the population that created it has historically maintained it is also modifying the socio-economic system. Territorial and socio-economic structures maintain a constant and reciprocal interaction. Thus, socio-economic processes are the main cause of changes in land uses, which basically determine the structure, function and dynamics of landscapes. Changes in social structures and processes lead to an alteration of the environment (Lorenzoni et al., 2000; Wang and Zhang, 2001; Wu and Hobbs, 2002).

With regard to methods, there has been a lack of consistency in defining and quantifying metrics regarding the role played by humans in modifying agro-ecosystems. Modeling and simulating the effects of human factors on landscape change remain a challenge for ecological research (Flamm y Turner, 1994). This limits the integration of data and models from the natural and social sciences. Furthermore, ecological and socio-economic information must be integrated for land planning and management (Matthews, 2006; Lacitignola et al., 2007).

De Aranzábal et al. (2008) studied the relationship between landscape structure and the underlying socio-economy. Depending upon the territory they considered, the relationship was intense or weak, but there was a need to quantify it to better understand humandominated ecosystems. They applied numerical models that relate ecological, economic and socio-cultural aspects, enabling them to predict new landscape types by means of a scenario-based approach for establishing socio-economic change. Their results permit them to predict the consequences on the nature of socio-economic changes generated by exogenous circumstances.

Serra et al. (2008) conducted a spatial analysis to examine the main driving forces of land cover and land use change in a Mediterranean region. Three tools were used to differentiate LCLU changes, driving forces and landscape dynamics. Land cover and land use changes were quantified with remote sensing techniques, driving forces were analyzed with multiple logistic regressions that combined biophysical and human variables, and landscape dynamics were quantified using various metrics. 
In the opinion of Dendoncker et al. (2007), statistical analyses of land use drivers rarely deal explicitly with spatial autocorrelation. Most studies are undertaken on autocorrelationfree data. Therefore, a great deal of information in the dataset is lost. Dendoncker et al. (2007) present a spatially explicit, cross-sectional analysis of land use drivers. They show that purely regressive logistic models only identify trends or global relationships between socio-economic or physical-climatic drivers and the precise location of each land use type. When the study goal is only to obtain the best statistical model fit of land use distribution, a purely autoregressive model is appropriate. This type of model deals appropriately with spatial autocorrelation, as measured by the lack of autocorrelation in the residuals of the model. Specifically, three autoregressive models were compared: (1) a set of binomial logistic regression models that account only for the proportion of the modeled land use within the neighborhood of a cell; (2) a multinomial autologistic regression that accounts for the composition of a cell's neighborhood; and (3) a state-of-the-art Bayesian Maximum Entropy model that accounts fully for the spatial organization of the land uses within the neighborhood of a cell (Dendoncker et al., 2007).

\subsection{Research questions and hypothesis}

Mid-size cities in the study area are experiencing increased urbanization and consequently there is a concentration of population and economic resources in urban areas. At the same time, there has been pronounced depopulation of rural areas, especially mountainous areas that are difficult to access.

The dynamics associated with travel between cities and high-capacity communication networks (roads, highways, etc.), along with urban expansion and settlement relocation, has caused major changes to human agricultural systems (row cropping, silviculture and cattle ranching).

This research was designed to determine and to evaluate the impacts of urban development and demographic trends on the natural and traditional areas (cultural landscapes) of the region. Among the specific issues investigated were the under-exploitation of resources in most rural areas (abandonment of lands, reversion of forest lands to second-growth vegetation causing greater fire risk, etc.), as well as growing pressure in urban areas (urban sprawl, construction of large shopping centers, etc.).

A review of the literature on land cover and land use changes and the new socioeconomic dynamics, raises new research questions. These questions include the following: 1) to what degree do land cover and land use changes affect the socioeconomic and environmental structure of the study area? 2) has the landscape of the Raya Central Ibérica changed similarly on both sides of the border during the period of analysis? 3) what are the major changes taking place? 4) does biodiversity increase with the land cover and land use changes in the Raya Central Ibérica? 5) does the quality of life improve with the land cover and land use changes in the area of study? 6) is it possible to reach a point of excessive urban growth in the Raya Central Ibérica? 7) are rural areas becoming depopulated? 8) are individuals who remain in the rural zones of the Raya Central Ibérica largely older people? With these specific questions in mind, the following general hypothesis was addressed: Can a statistical method like a generalized linear model be used to identify the principal socioeconomic and 
physical factors that drive land cover and land use changes in the border region of Spain and Portugal?

The approach used in this study assesses a great variety of socioeconomic, biophysical and climatic factors, operating across a range of spatial scales and one temporal dimension in order to understand the distribution of land covers and land uses (Schmitz et al., 2003; Hietel et al., 2005; Millington et al., 2007). Application of this pattern to a transnational region is one of the major contributions of this research project. Most of the existing studies on land cover and land use changes are mainly applied to small areas: municipalities, counties, protected natural areas (Romero-Calcerrada and Perry, 2004; Serra et al., 2008; De Aranzabal et al., 2008), while this study reflects on a cross-border area that covers a larger territorial entity. Analysis of the cross-border space is based on the data provided by the CORINE project, since this is synthetic and homogeneous data calculated through similar methodologies in all EU countries. Since this is a regional level study, relations between changing patterns of land cover and use and their spatial determinants are more complex. The study reveals social and natural causes of land degradation that can be used for future regional planning purposes.

\section{STUDY AREA}

Despite the lack of consensus regarding the definition of «border» or its spatial extent, a transnational region was chosen to study territorial dynamics and their impacts on regional land cover and land use changes. The study encompasses the «provinces» of Extremadura, Spain (Cáceres and Badajoz) and five Portuguese «districts» that share border with Extremadura (Guarda, Castelo Branco, Portalegre, Évora and Beja).

In the Spanish case, both «provinces» belong to the same «region,» whereas in Portugal, two «districts» belong to the Región Centro (Guarda and Castelo Branco), and the three most southern «districts» pertain to the Región Alentejo (Portalegre, Évora and Beja). This cross-border area has been referred to as Raya Central Ibérica by many authors (Cabero et al., 1995-1996; Campesino, 1997, 2007; López et al., 1997; Mora, 1997), and this name is used here. Nevertheless, it must be mentioned that the exact limits of the region differ from one article to another, though the general range of the territory is the same for all. The municipalities in this area are seen in Figure 1.

Three regions within the Raya Central Ibérica were identified as Target 1 areas of the EU, meaning that these areas receive «structural» and «cohesion» funds to correct economic imbalances. These infusions of support have altered this area considerably. The analyzed zone has been the subject of a community policy that formed through another funding initiative, INTERREG, and contributions of assistance enabled the purchase of equipment and creation of infrastructure, which influence the region's functionality and determine land cover and land use.

The environment of the Raya Central Ibérica is defined by: 1) the mountainous region of the Sistema Central in Extremadura and its extension into Portugal across the Serra da Malcata and the Serra da Estrela, 2) the Palaezoic mountain ranges such as the Sierra de San Pedro or Las Villuercas, 3) the extensive flat plains in Extremadura (Penillanura Cacereña and La Serena) and in Portugal (Penillanura Alentejana), and 4) the large depression of the 


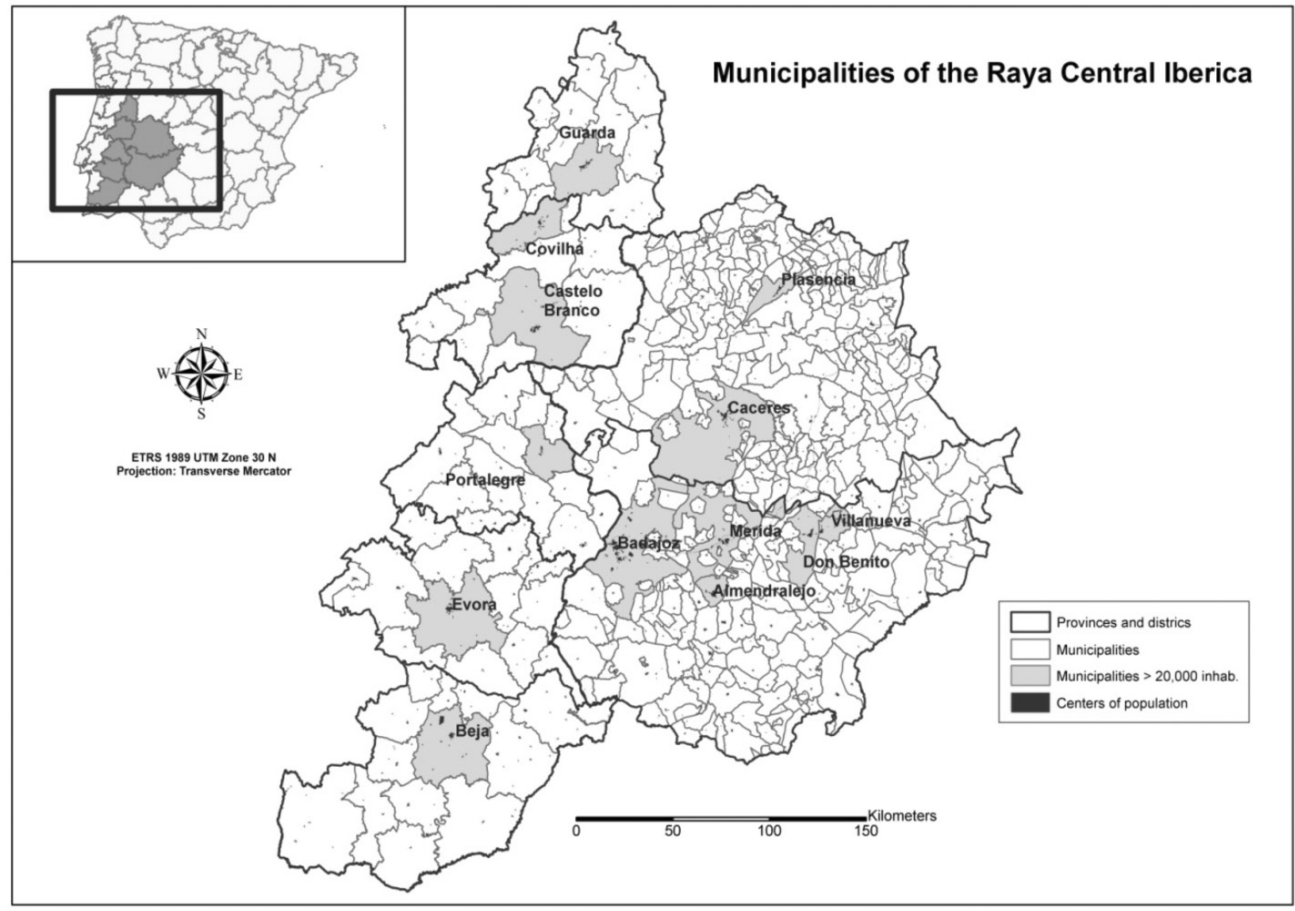

Sources: Statistics National Institute of Spain and CORINE Land Cover - I\&CLC2000 Project - Spain (IGN, CNIG); and Statistics Portugal and CORINE Land Cover - I\&CLC2000 Project- Portugal (IA and IGP). The authors.

Tajo and Guadiana rivers. Figure 2 is a geomorphologic and environmental map of the area under study.

In regard to morfo-structurals units, starting with the Extremadura territory, several systems can be differentiated like the Sistema Central, to the North, organized in a series of structures, from the lowest tectonic depressions (Tiétar-Ambroz-Alagón-Árrago), until the principal elevations. Then, a peneplain that spans most of Extremadura, dotted with waste mountain reliefs with granitic plutons highlights and higher blocks. The northernmost peneplain deeply fits the Tajo River and its river network. The peneplain is divided into two halves by the Sierra de Montánchez and Sierra de San Pedro and the depression of the Guadiana river. The depression of the Guadiana river is a large sedimentary basin to the North of the province of Badajoz that disappears when it reaches the River border layout. The pool of the Guadiana, with many marshes and reservoirs, with deep and fertile soils, has expanded the irrigated land along the entire basin. Finally, a range of continuous elevations, lowlands and not very abrupt slopes follow to the South, comprising the Extremaduran set of Sierra Morena. 
Five Portuguese districts, on the other side, are part of the Raya Central Iberian area under analysis and are situated on the western end of the former base of the Iberian plateau and composed of granitic rocks that are superimposed sedimentary formations. The morphology is not uniform, but it presents a succession of mountain ridges, terraces, hills and plains that descend from the Spanish plateaus into the Atlantic. The Tajo separates the northern part and mountainous of the Portuguese territory which are part of the districts of Castelo Branco and above all Guarda, Central Portugal, essentially flat, whose greatest exponent is the plateau of Alentejo, surrounded to the South by the hills of the Algarve, South of the District of Beja. The Portuguese coast is usually rectilinear and little cropped, but you can see an example of the unique coastal district of the entire area of study: Odemira.

Figure 2

GEOMORPHOLOGY AND ENVIRONMENT OF THE STUDYAREA

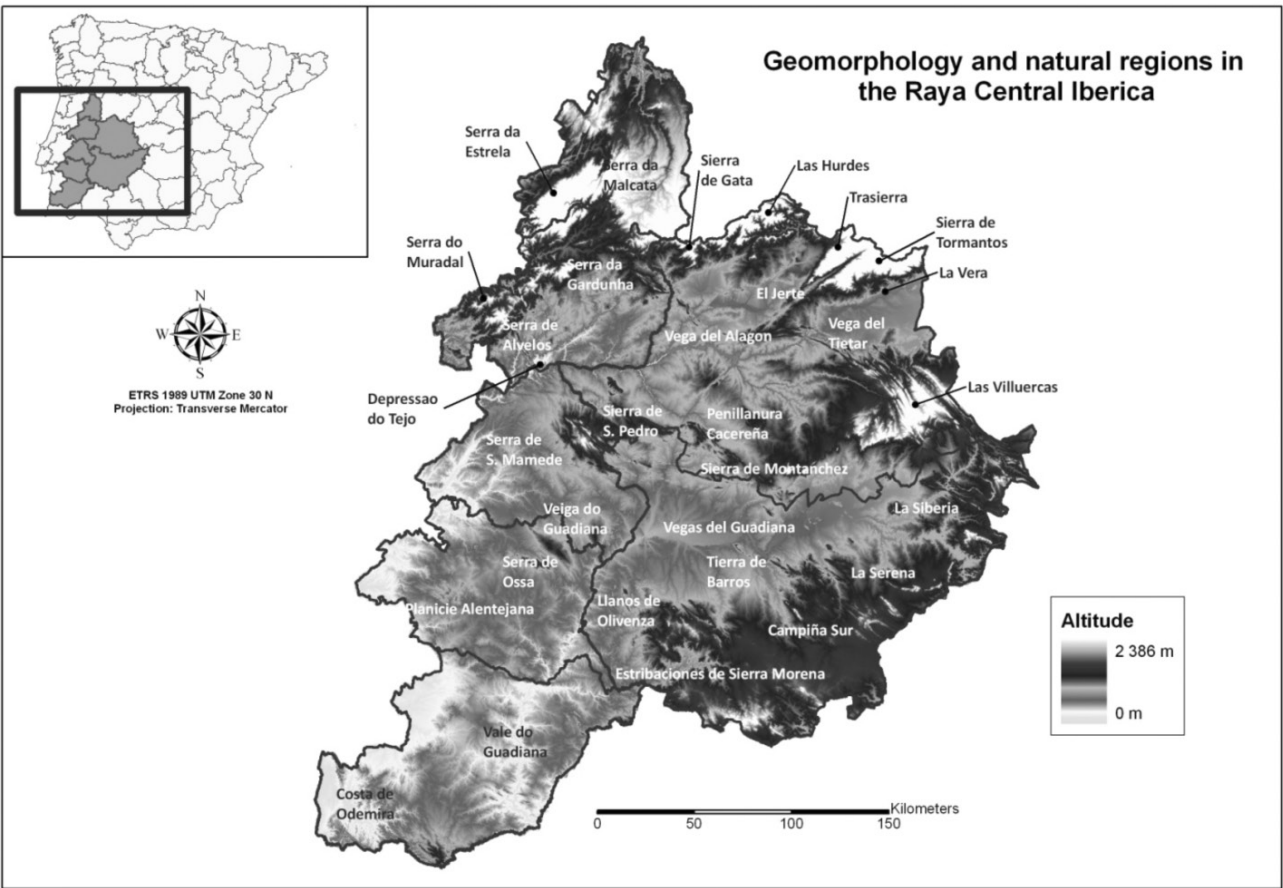

Source: Consortium for Spatial Information (CGIAR-CSI), NASA Shuttle Radar Topographic Mission (SRTM). The authors.

Therefore, the Raya Central Ibérica is part of the eroded Hesperian massif, which has given rise to the surface of erosion of the peneplain, only rugged by soft undulations, residual reliefs and blocks uneven at different altitudes, including important mountains and sedimentary depressions of the Tagus, the Guadiana river and its tributaries. The study area offers a mineralogical wealth, while soils are, in general, rickety and poor, low productivity and rather vocational mixture of agriculture, forestry and pastoral, with the exception of the sedimentary depressions. 
In regard to the climatic particularities, the Iberian Central Bay is located in the temperate zone of the northern hemisphere and is under the influence of the prevailing winds from the West, on the basis of General atmospheric circulation. By its location and opening to the Atlantic, is a temperate climate, anti-aliasing and humid, although there are other atmospheric factors which introduce significant modifications. There are two distinct seasons: the cold season with excess of rainfall, and the summer season with a strong deficit moisture, allowing to characterize this as a Mediterranean climate, with mild and wet winters as a result of the oceanic influence, and very hot and dry summers conditioned by anticyclone effect of the Azores. One of the most notable characteristics of rainfall in the Raya Central Ibérica is the inter-annual irregularity happening in spring and fall and representing rainiest season of the year. In regard to temperatures, these show a distinct pattern from North to South. The spring and summer are sunny and the highest temperatures are during July and August, while January is the month of lowest temperatures.

\section{MATERIALS AND METHODS}

Socioeconomic, agricultural, accessibility and geophysical variables (Table 1) were used as independent variables in the generalized linear models. These independent variables, also called explanatory variables or driving forces, were those factors that influenced land cover and land use changes in the study area over the period analyzed.

Table 1

INDEPENDENCE VARIABLES

\begin{tabular}{|l|l|l|l|}
\hline \multicolumn{3}{|c|}{ Independence variables } \\
\hline Socieconomic variables & Agricultural variables & \multicolumn{1}{|c|}{ Accessibility variables } & \multicolumn{1}{|c|}{ Geophysical variables } \\
\hline Population & Head of cattle $/ \mathrm{Ha}$ & Population potential in 30 minutes & Natural reserve $($ municipal percentage) \\
Population growth & Head of sheep $/ \mathrm{Ha}$ & Minimal time Peninsula Iberica $(\text { min. })^{2}$ & Altitude $(\mathrm{m})$ \\
Birth rate & Head of goat $/ \mathrm{Ha}$ & Minimal time Raya Central Iberica $(\text { min. })^{3}$ & Slope \\
Death rate & Head of pigs $/ \mathrm{Ha}$ & Distance closest highway $($ Km. $)$ & Precipitation: annual average $\left(l / \mathrm{m}^{2}\right)$ \\
Arithmetic mean age & Farm machinery $/ \mathrm{Ha}$ & & Temperature: annual average $\left({ }^{\circ} \mathrm{C}\right)$ \\
Youth rate & Farm holders $<34$ years & & \\
Aging rate & Farm holders $35-54$ years & & \\
Dependence index & Farm holders $>65$ years & & \\
University studies & & & \\
Activity rate & & & \\
Agricultural sector & & & \\
Industry sector & & & \\
Tertiary sector & & & \\
\hline
\end{tabular}

Sources: Statistics National Institute of Spain and Statistics Portugal and Department of Public Works, Transport and Housing of Spain and Portugal The authors.

2 Minimal time in minutes to the nearest economic activity center ( $>200,000$ inhabitant) in the Peninsula Iberica.

3 Minimal time in minutes to the nearest economic activity center ( $>20,000$ inhabitants) in the Raya Central Iberica. 
Independent socioeconomic and geophysical variables for the Raya Central Ibérica study were selected using previously published work and an exploration of correlations or redundancies among the potential independent variables. At the outset, only a descriptive analysis of the socioeconomic and geophysical variables was undertaken. Variables that had problems with colinearity, correlation or were lacking in homogeneity, were eliminated. Ultimately, 30 entry variables were used. The alphanumeric information applied in this first analysis was obtained from diverse sources: the National Institute of Statistics of Spain and Portugal, the Department of Public Works, Transport and Housing of Spain and Portugal, the Consortium for Spatial Information, NASA Shuttle Radar Topographic Mission, the Meteorological Service of the Department of Defense of Spain and the Geographical Institute of Spain and Portugal.

Data on land occupation and land cover and land use changes were obtained from the CORINE Program. The Geographical Institute of Spain and the Institute of the Environment and Geographical Institute of Portugal managed the CORINE Land Cover 1990 Project in Spain and Portugal between 1987 and 1991, under the supervision of the European Commission. The European Environment Agency initiated an update in the late 1990s to obtain information on trends in land occupation. The new project had two related components. The first one, Image 2000, included activities related to the acquisition of satellite images of all of Europe and their ortho-rectification. The second, CORINE Land Cover 2000, was designed to detect and interpret land cover changes in the period 1990-20004.

In our study, two independent analyses were carried out. The first looked at the replacement of one land cover category by another in the CLC Project-Levels 1 and 3 (Table 2 ) and the second analyzed the net change of surfaces occurring in the study area over the period of interest.

Several steps were required to evaluate land cover changes between 1990 and 2000. In the first step we calculated at the municipal level the surface area occupied by each land use in Levels 1 and 3. After that, we calculated the land cover changes that took place in each municipality, between one type of cover and another.

Subsequently, we determined the land cover and land use changes for each municipality using Geographic Information Systems (spatial analysis consisting of the geometric computation). The resulting table of attributes, updated automatically, was the one used for further analysis. Next, the surface area of each row (the different land use changes in each municipality) was calculated.

Data from the GIS was imported into a database management system to obtain land cover changes at the municipal level in absolute values, such as percent cover. This exercise had two objectives. First, it was done to show the different types of land cover changes that occurred in each municipality as well as the surface areas involved. Second, it was

4 One of the limitations of this research project is that the data used is a bit outdated. This problem was outside our control as it coincided the period of development of the Doctoral thesis and with the intercensal period when new homogeneous and synthetic data of land cover and land use for both countries has not been published. While the latter CORINE project dates back to 2006, its publication has not been effective so far. While the 2006 CORINE project of Portugal data are available since the autumn of 2009 , in the case of Spain, these data is available for public downloads of the National Center for Geographic Information from March 2010 which was only a few weeks before opening up for regular public application through mail or email. 
Table 2

CORINE LAND COVER NOMENCLATURES

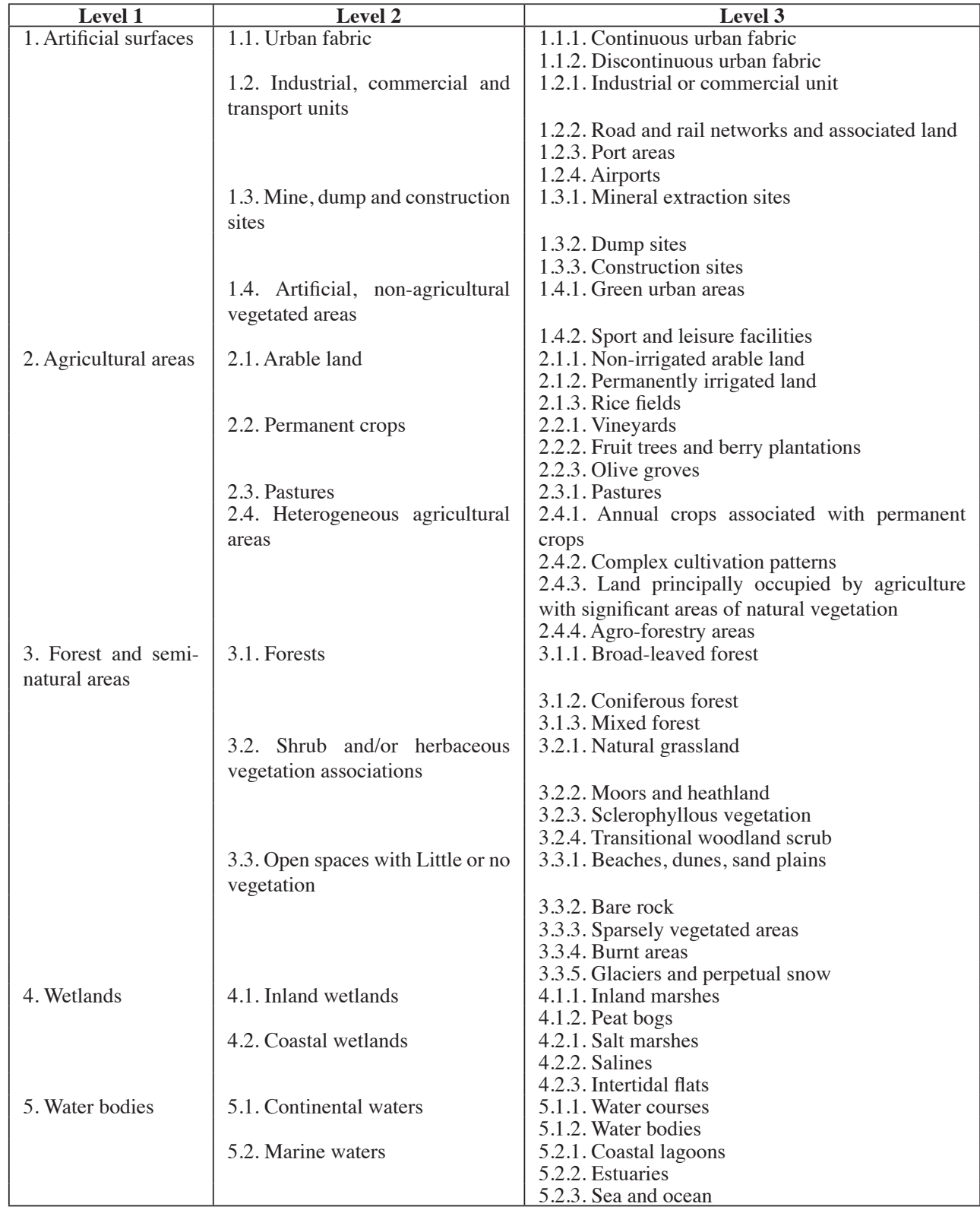

Sources: National Geographic Institute of Spain (Spanish $I G N$ ), National Center of Geographic Information of Spain (Spanish CNIG) -Department of Transport and Housing; Environment Institute (Portuguese IA) and Portuguese Geographical Institute (Portuguese $I G P$ ) -Department of Environment, Spatial Planning and Regional Development of Portugal. 
undertaken to produce a table that shows the percentage of municipal surface area affected by each land cover change, i.e. from one land cover category to another. The table resulting from the second analysis could be imported into a Geographical Information System to map the land cover change types at the municipal level in the Raya Central Ibérica.

To carry out the analysis of the net change for each land cover at the municipal level, the final table from the previous analysis is required. The table is exported to the database management system, and statistical operations are executed to obtain the net changes in surface area for each land cover.

It is important to note that shifts in land cover over time are complex. For any one land cover type, some area may be lost to other land covers, whereas some area may be gained from other land covers. Calculation of the net change in a land cover type requires an equation that sums these gains and losses ${ }^{5}$. After obtaining the net change in land cover between the years 1990 and 2000, the resultant table was imported into a Geographical Information System to produce a map.

The main goal of this work was to analyze land occupation and land cover and land use changes, over the period of interest. But we also sought to determine the driving geophysical and socioeconomic factors that determined land cover and land use changes from 1990 to 2000 .

This study used logistic regression as a technique to explain the land cover changes. Specifically, Generalized Linear Models (GLM) of the statistical program $\mathrm{R}^{6}$ were used. The linear models are based on a series of assumptions, some of which must be verified once the model is fitted. These are: independency, linearity, normality or homoscedasticity of the data. In some cases, one or more of these assumptions may not be valid. In such cases, the response variables can be transformed (e.g. log transformation). Sometimes, however, even these transformations cannot correct the lack of normality, the heteroscedasticity (differing variances) or non-linearity of the information ${ }^{7}$. An alternative to the transformation of the response variable and to the lack of normality is the use of generalized linear models. These are extended linear models that allow using data with non-normal distributions and differing variances.

Certain types of dependent variables invariably violate the assumptions of the normal models, and GLMs offer a good alternative in such cases. For instance, GLMs are often used when the response variable is expressed as a proportion or as a binary response. In this study, we used a binary response variable, i.e. increase of the land cover area (1) and decrease or no change of the land cover area (0). We give the same value to decrease and no change although this is different; also this does not include whether a change is insignificant and important. The use of GLMs in this case was most appropriate.

Many of the most common statistical methods, such as regressions, assume that the variance is constant, but in many cases this is not so. In such cases, GLMs can be quite useful (Cayuela, 2009 a and b; Le Sage and Kelley, 2009).

5 Example: $=($ SUMA(CLC_N1!C2;CLC_N1!I2;CLC_N1!L2;-CLC_N1!F2;-CLC_N1!G2) $)$.

$6 \mathrm{R}$ is a system for the implementation of statistical functions and creation of graphs. In a broader sense, $\mathrm{R}$ is thought of as a programming language with a set of implemented procedures that allows to carry out diverse tasks, which range from the application of statistical functions to the generation and resolution of multiple problems (Crawley, 2005, 2007; Cayuela, 2009 c).

7 Neither can it overcome one of the most important problems in spatial analysis, the phenomenon of spatial autocorrelation, which can also occur in the residuals of a regression. 


\section{RESULTS}

\section{IV.1. Territorial characterization}

The following major conclusions can be drawn from the socio-economic and physical characterization of the study area (Table 3): 1) there was a population decline in the rural areas, 2) young people leave rural areas, while older individuals remain, 3) many unemployed individuals depend on a small segment of the population that is employed, 4) the agricultural sector (silviculture, crop production, cattle ranching) is economically important in rural

Table 3

INDEPENDENCE VARIABLES: SOCIOECONOMIC AND PHYSICAL (MUNICIPAL AVERAGE)

\begin{tabular}{|l|r|}
\hline \multicolumn{2}{|c|}{ Socioeconomic and physical variables } \\
\hline Variable & Value \\
\hline Population & $4,214.94$ \\
Population growth & $-0.85 \%$ \\
Birth rate & 7.22 \\
Death rate & 13.28 \\
Arithmetic mean age & 44.10 \\
Youth rate & $15.53 \%$ \\
Aging rate & $26.79 \%$ \\
Dependence index & $69.17 \%$ \\
University studies & $4.96 \%$ \\
Activity rate & $44.88 \%$ \\
Agricultural sector & $26.23 \%$ \\
Industry sector & $26.52 \%$ \\
Tertiary sector & $47.25 \%$ \\
Head of cattle/Ha & 16.38 \\
Head of sheep/Ha & 90.64 \\
Head of goat/Ha & 11.20 \\
Head of pigs/Ha & 23.18 \\
Farm machinery/Ha & 1.93 \\
Farm holders <34 years & $7.54 \%$ \\
Farm holders 35-54 years & $34.27 \%$ \\
Farm holders > 65 years & $33.83 \%$ \\
Population potential in 30 minutes & $89,539.13$ \\
Minimal time Peninsula Iberica (min.) & 115.42 \\
Minimal time Raya Central Iberica (min.) & 32.17 \\
Distance closest highway $($ Km.) & $21,682.16$ \\
Natural reserve (municipal percentage) & $26.67 \%$ \\
Altitude (m) & 449.24 \\
Slope & $23.74 \%$ \\
Precipitation: annual average $\left(1 / \mathrm{m}^{2}\right)$ & 621.45 \\
Temperature: annual average $\left({ }^{\circ} \mathrm{C}\right)$ & 15.40 \\
\hline
\end{tabular}

Sources: Statistics National Institute of Spain and Statistics Portugal and Department of Public Works, Transport and Housing of Spain and Portugal The authors. 
areas, 5) there was an exodus of rural population to cities, 6) there are geomorphologic peculiarities in the area, 7) the Mediterranean climate with Atlantic influence, affects natural and agricultural systems in the region.

Today, many people in the Raya Central Ibérica are leaving rural areas and resettling in the principal cities. This migration, which has caused pronounced land use changes, is a consequence of a territorial model that in Portugal is characterized by the following factors: highly dispersed population with nucleated population centers, duplication of equipment and services, and concentration of the population in coastal areas. On the Spanish side of the border, the population is increasingly concentrated in the principal cities as rural areas are abandoned, leaving behind an aged population in rural regions. Nevertheless, rural municipalities of eastern Portugal are also experiencing emigration, along with the problems of aging populations and marginal socioeconomic systems. These factors are a great disadvantage for territorial development, in addition to the original problems (as forest fires) that were provoked by land cover/land use changes and abandonment of rural lands (Jaraíz, 2011; Regidor, 2006).

In Extremadura, rural population are separated from the principal regional and national cities, by great distances. They are connected by a public transport system with limited service. This has led to creation of remote and marginalized rural populations. The inability to efficiently connect rural and urban areas across a broad region has contributed to the abandonment of the rural. Rural residents encounter a lack of opportunity and must migrate to the city to find employment and services.

\section{IV.2. Regional analysis of land cover change}

Analysis of land cover/land use changes in the Raya Central Ibérica led to several major conclusions: 1) agricultural (56.58\%) and forest covers (41.89\%) predominate, 2) there has been expansion of artificial surfaces (+9,274.71 ha) despite low density and weak infrastructure of urban areas, 3$)$ there has been expansion of irrigated lands $(+64,376.49$ ha) and consolidation ( $+64,376.49$ ha) of agro-forestry areas (annual crops or grazing land under the wooded cover of forestry species), 4) there has been a decrease of sclerophyllous vegetation $(-41,070.52 \mathrm{ha})$ and an increase in broad-leaf forest $(+40,421.74 \mathrm{ha}), 5)$ there has been an increase in water bodies $(+17,309.1$ ha), 6) the Common Agricultural Policy has caused changes in agricultural areas,7) forest fires have become more problematic, and, 8) depopulation of rural areas caused changes in land cover/land use.

With regard to land cover in the study area, agro-forestry $(19.58 \%)$ and non-irrigated arable lands $(18.76 \%)$ characterize the landscape. The dehesa (Spanish) or montado (Portuguese) agro-forestry areas, where oaks (Quercus sp.) grow, constitute the predominant land use in the agricultural areas (34.60\%). In the same way, in terms of spatial extent, forests and semi-natural areas $(3,361,669.97 \mathrm{ha})$ are a very important land cover. Forest surfaces are dominant within this category (38.21\%). Other common elements are reservoirs $(78,590.39$ ha), including important water bodies in the Extremaduran region, such as those on the Tajo and Guadiana rivers. Artificial surfaces within the study area are few (44,736.95 ha). Within the three of the regions of the Península Ibérica, there are no large population centers, and hence only a small percentage of artificial zones. 
Table 4

DETERMINING CHANGES AND FLOWS IN RAYA CENTRAL IBERICA LAND COVERAND LAND USE USING CORINE (IN KMํ)

\begin{tabular}{|l|c|c|c|}
\hline \multicolumn{3}{|c|}{ Determining changes and flows in Raya Central Iberica land cover and land use using CORINE } \\
\hline & Total change area & $\begin{array}{c}\text { Change area/total } \\
\text { change area }\end{array}$ & $\begin{array}{c}\text { Change area/ } \\
\text { total Raya Central } \\
\text { Iberica area }\end{array}$ \\
\hline Undefined & 58.71 & $0.89 \%$ & $0.06 \%$ \\
Urbanisation & 122.59 & $1.86 \%$ & $0.12 \%$ \\
Intensification of agriculture & $1,814.23$ & $27.49 \%$ & $1.72 \%$ \\
Extensification of agriculture & 162.31 & $2.46 \%$ & $0.15 \%$ \\
Afforestation & $2,354.38$ & $35.67 \%$ & $2.23 \%$ \\
Deforestation & $1,879.11$ & $28.47 \%$ & $1.78 \%$ \\
Water bodies construction & 208.20 & $3.15 \%$ & $0.20 \%$ \\
Total flows in land cover/use & $6,599.53$ & $100.00 \%$ & $6.25 \%$ \\
\hline
\end{tabular}

Sources: CORINE Land Cover - I\&CLC2000 Project - Spain (IGN, CNIG) and CORINE Land Cover I\&CLC2000 Project- Portugal (IA and IGP). The authors.

With respect to land cover/land use change (Table 4), we first will address the expansion of artificial surfaces between 1990 and 2000 (+9,274.71 ha). Within urban zones, «urban discontinuous fabric» constitutes a major surface $(17,598.77$ ha). Industrial or commercial units are another type of important artificial surface in the study territory (4,815.10 ha). The Raya Central Ibérica experienced an important change with respect to road networks, through improvement of existing roads and construction of new ones (504.02).

Analysis of agricultural areas emphasizes the predominance of agro-forestry areas in the three regions of the Raya Central Ibérica (1,571,190.97 ha) and throughout the southwest of the Península Ibérica. Agro-forestry is followed in importance by non-irrigated arable lands $(1,505,292.02$ ha). Net changes in land use through the decade of the 1990s indicate a decline in coverage of non-irrigated arable land (-83,755.87 ha) in favor of irrigated lands and agro-forestry areas. Consequently, the least productive agricultural land uses are far from irrigation infrastructure and are increasingly abandoned.

Forest and semi-natural areas is the land cover that diminished most over the studied period $(-34,073.38 \mathrm{ha} ;-1.00 \%)$. Within the forest areas, the most affected zones were

8 Feranec et al., 2010:

Urbanisation: a flow which represents the change of agricultural and forest land, wetlands into urbanized land (the construction of buildings designed for living, education, health care, recreation and sport) as well as industrialized land (the construction of facilities for production, all forms transport and electric power generation).

Intersification of agriculture: a flow which represents the transition of land cover types associated with lower intensity use into the higher intensity use. The internal conversion of agriculture in a sense of more intensive use is also included in this flow.This characteristic accepts general principles of agricultural production (involving more inputs per unit land to raise productivity) in the context of the analysed lad cover classes.

Extensification of agriculture: a flow which represents the transition of the LC type, associated with a higher intensity use to the lower intensity use. It involves mainly the social response to land constraints.

Afforestation: a flow which represents forest regeneration - the establishment of forests by planting and/or natural regeneration.

Deforestation: a flow involving forest land change into another land cover or damaged forest.

Water bodies construction: a flow involving the change of mainly agricultural and forest land into water bodies. 
those with sclerophyllous vegetation $(-41,070.52 \mathrm{ha})$, followed by the coniferous forests $(-32,151.28 \mathrm{ha})$. Despite the loss of forest areas, the surface of broad-leaf forest $(40,421.74$ ha) and transitional woodland scrub (22,370.29 ha) increased. Broad-leaf forest cover increased as a consequence of reforestation programs and natural regeneration of broad-leaf vegetation on abandoned agricultural fields.

Water bodies in the Raya Central Ibérica cover a significant part of the territory $(0.98 \%)$, mostly in Extremadura. Water bodies expanded their coverage (19,695.85 ha) during the study interval as dams were constructed to produce reservoirs for energy production, drinking water and irrigation.

\section{IV.3. Land cover/land use exchanges and net changes in municipalities}

At Level 1, the major land cover exchanges (average statistics of the municipalities without taking into account the size of the same) in the Raya Central Ibérica were: 1) switch from forest areas to agricultural areas $(1.35 \%)$, 2) from agricultural areas to forest areas $(0.67 \%), 3)$ from forest areas to water bodies $(0.20 \%)$, and 4$)$ from agricultural areas to water bodies $(0.12 \%)$. Of the combinations of possible cover exchanges at Level 3, the most important (Table 5) were: 1) from transitional woodland scrub to agro-forestry areas $(0.70 \%), 2)$ from sclerophyllous vegetation to transitional woodland scrub $(0.49 \%), 3)$ from broad-leaved forest to transitional woodland scrub $(0.37 \%), 4)$ and from coniferous forests to transitional woodland scrub $(0.35 \%)$.

Table 5

MEAN OF THE PRINCIPAL LAND COVER AND LAND USE EXCHANGES AT LEVEL 3

\begin{tabular}{|c|l|c|}
\hline Id & Land cover and land use exchange & Mean \\
\hline 1 & Transitional woodland scrub to agro-forestry areas & $0.70 \%$ \\
2 & Sclerophyllous vegetation to transitional woodland scrub & $0.49 \%$ \\
3 & Broad-leaved forest to transitional woodland scrub & $0.37 \%$ \\
4 & Coniferous forest to transitional woodland scrub & $0.35 \%$ \\
5 & Non-irrigated arable land to irrigated land & $0.33 \%$ \\
6 & Transitional woodland scrub to broad-leaved forest & $0.33 \%$ \\
7 & Non-irrigated arable land to natural grassland & $0.31 \%$ \\
8 & Irrigated land to other irrigated land & $0.22 \%$ \\
\hline
\end{tabular}

Sources: CORINE Land Cover - I\&CLC2000 Project - Spain (IGN, CNIG) and CORINE Land Cover I\&CLC2000 Project- Portugal (IA and IGP). The authors.

With respect to land cover/land use net changes at Level 1 in the municipalities of the Raya Central Ibérica, the surface that on average expanded most was agricultural areas (Figure 3). Water bodies and artificial surfaces also expanded. As these three covers grew in coverage during the study period, forest and semi-natural areas decreased. These forest areas, however, are composed not only of forest species, but by shrub or herbaceous vegetation also. They also may contain open spaces with little or no vegetation. Not everything that was lost had been covered by forest trees. 
Figure 3

MEAN OF THE PRINCIPAL LAND COVER/LAND USE NET CHANGES AT LEVEL 1

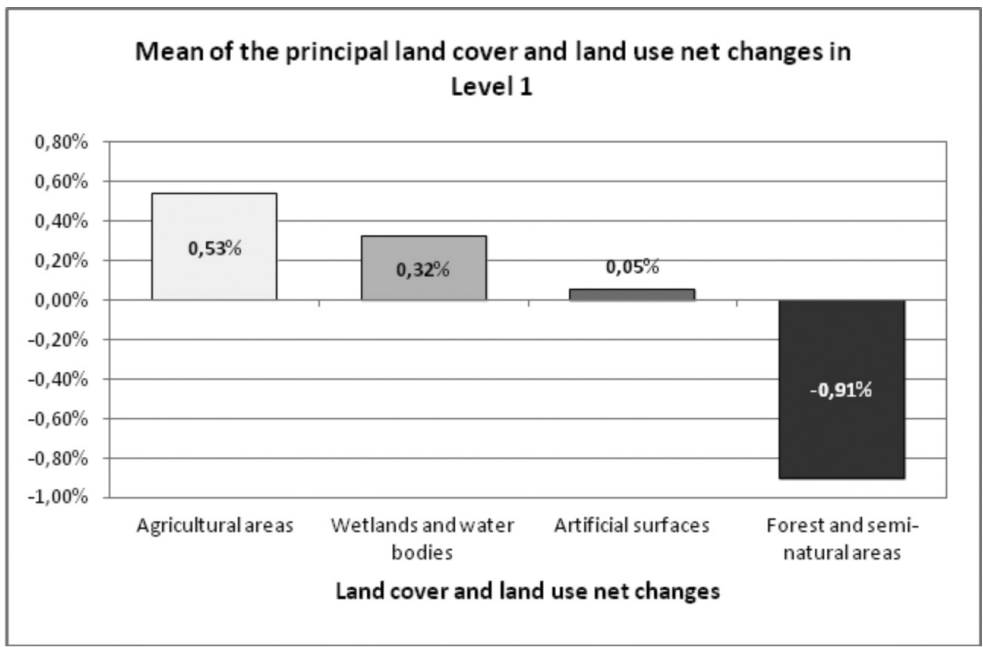

Sources: CORINE Land Cover - I\&CLC2000 Project - Spain (IGN, CNIG) and CORINE Land Cover I\&CLC2000 Project- Portugal (IA and IGP). The authors.

In the Raya Central Ibérica, the land cover and land use at Level 3 that most increase their surface in municipal areas were (Table 6): 1) permanently irrigated land $(0.62 \%), 2)$ agro-forestry areas $(0.53 \%), 3)$ transitional woodland scrub $(0.40 \%)$, and 4$)$ water bodies $(0.32 \%)$. Expansion of irrigated land and agro-forestry areas confirms the importance of the agricultural sector. The increase of woodland scrub is attributed mostly to its expansion into abandoned agricultural areas.

Table 6

PRINCIPAL STATISTICS OF THE LAND COVER/LAND USE NET CHANGES AT LEVEL 3 (\%). POSITIVE MEAN

\begin{tabular}{|l|c|c|c|c|}
\hline \multicolumn{1}{|c|}{ Land cover } & Mean & Maximum & Minimum & $\begin{array}{c}\text { Standard } \\
\text { deviation }\end{array}$ \\
\hline Permanently irrigated land & 0.623 & 56.500 & -1.633 & 3.551 \\
Agro-forestry areas & 0.534 & 18.586 & -21.674 & 2.452 \\
Transitional woodland scrub & 0.397 & 34.697 & -16.917 & 4.231 \\
Water bodies & 0.320 & 18.097 & -0.533 & 1.768 \\
Vineyards & 0.057 & 5.736 & -1.853 & 0.484 \\
Natural grassland & 0.040 & 13.456 & -16.345 & 2.032 \\
Fruit trees and berry plantations & 0.026 & 2.097 & -2.225 & 0.245 \\
Olive groves & 0.022 & 8.073 & -5.680 & 0.579 \\
Mineral extraction sites & 0.019 & 1.670 & 0.000 & 0.123 \\
Industrial or commercial unit & 0.018 & 1.625 & 0.000 & 0.102 \\
\hline
\end{tabular}

Sources: CORINE Land Cover - I\&CLC2000 Project - Spain (IGN, CNIG) and CORINE Land Cover I\&CLC2000 Project- Portugal (IA and IGP). The authors. 
Several land cover/land use types displayed negative mean shifts at Level 3 (Table 7): 1) sclerophyllous vegetation $(-0.84 \%), 2)$ non-irrigated arable land $(-0.62 \%), 3)$ burned areas $(-0.23 \%)$, and 4$)$ coniferous forests $(-0.15 \%)$. The cover that lost most coverage at the municipal level was sclerophyllous vegetation, which became either natural grassland or woodland scrub, the latter indicating a process of reforestation. The decline in burned areas is probably attributable to natural forest recovery. Non-irrigated arable land likely declined in coverage because it is low in productivity and consequently does not receive subsidies from the European Union. Instead, more productive lands are the beneficiaries of such aid.

Table 7

PRINCIPAL STATISTICS OF THE LAND COVER/LAND USE NET CHANGES AT LEVEL 3 (\%). NEGATIVE MEAN

\begin{tabular}{|l|c|c|c|c|}
\hline \multicolumn{1}{|c|}{ Land cover } & Mean & Maximum & Minimum & $\begin{array}{c}\text { Standard } \\
\text { deviation }\end{array}$ \\
\hline Sclerophyllous vegetation & -0.843 & 14.078 & -34.697 & 3.166 \\
Non-irrigated arable land & -0.627 & 16.345 & -36.187 & 2.690 \\
Burnt areas & -0.231 & 7.176 & -32.001 & 2.483 \\
Coniferous forests & -0.149 & 13.490 & -35.019 & 2.270 \\
Broad-leaved forest & -0.081 & 13.815 & -15.144 & 2.099 \\
Complex cultivation patterns & -0.079 & 4.437 & -11.547 & 0.918 \\
Moors and heathland & -0.025 & 3.671 & -6.401 & 0.468 \\
Pastures & -0.012 & 1.101 & -3.704 & 0.239 \\
Land principally occupied by agriculture & -0.010 & 4.074 & -3.990 & 0.480 \\
with areas of natural vegetation & & & & \\
Construction sites & -0.007 & 0.715 & -3.538 & 0.171 \\
\hline
\end{tabular}

Sources: CORINE Land Cover - I\&CLC2000 Project - Spain (IGN, CNIG) and CORINE Land Cover I\&CLC2000 Project- Portugal (IA and IGP). The authors.

\section{IV.4. Driving forces for land use/land cover change}

The principal results (Table 8) that emerged from the analysis using generalized linear models were: 1) it is important to integrate both human and geophysical factors into models of land cover/land use change, 2) lack of agricultural activity is associated with an increase in burned areas, 3) areas with abundant young people and substantial economic activity saw expansion in the coverage of vineyards, 4) growth of the urban discontinuous fabric is driven by population numbers, 5) there is positive correlation between population density and the quality of road and railway networks, 6) accessibility, infrastructure and population are all correlated with the artificial surfaces.

We create a boxplot to make the commentary of the results of the model more visual and attractive and resolved problems of interpretation of the tables generated by the generalized linear models. Once carried out a GLM for a dependent variable, we create a boxplot for each of the independent variables that most explain the land cover and land use, i.e., for those who have less than 0.05 in significance. 
Table 8

PRINCIPAL DEVIANCES OBTAINED FROM THE GENERALIZED LINEAR MODELS (\%)

\begin{tabular}{|l|c|}
\hline \multicolumn{2}{|c|}{ Deviance } \\
\hline \multicolumn{2}{|c|}{ Land covers and land uses } \\
\hline Level 3. Moors and heathland & 60.80 \\
Level 3. Burnt areas & 51.95 \\
Level 3. Vineyards & 47.24 \\
Level 3. Discontinuous urban fabric & 46.71 \\
Level 3. Road and rail networks & 44.51 \\
Level 1. Artificial surfaces & 42.52 \\
Level 3. Industrial or commercial unit & 39.71 \\
Level 3. Construction sites & 37.68 \\
Level 3. Mineral extraction sites & 36.49 \\
Level 3. Irrigated land & 35.14 \\
Level 3. Pastures & 32.70 \\
Level 3. Continuous urban fabric & 29.30 \\
Level 3. Mixed forest & 24.90 \\
Level 3. Olive groves & 23.03 \\
Level 3. Fruit trees and berry plantations & 22.81 \\
Level 3. Agro-forestry areas & 22.55 \\
Level 1. Forest and semi-natural areas & 21.58 \\
Level 3. Coniferous forests & 20.49 \\
Level 1. Water bodies & 20.19 \\
\hline
\end{tabular}

Sources: CORINE Land Cover - I\&CLC2000 Project - Spain (IGN. CNIG) and CORINE Land Cover I\&CLC2000 Project- Portugal (IA and IGP). The authors.

The boxplot serve to see the distribution of the values relative to the mean. The average in the figure is the black line that appears in the box. Out of the box are also other two lines, these lines representing the standard deviation. The box is more or less wide depending on the dispersion of the data relative to the mean. The points that are outside of the box and the lines of the standard deviation are the maximum and minimum outside the defined range. Ultimately, in these diagrams of boxes we appreciate the performance of the dependent or dichotomous variables, depending on each of the independent variables.

The model for cover of burned areas yielded very high and significant variance. The model indicates that the independent variables that best explain changes in the cover of burned areas are, in order of importance: 1) annual mean temperature of the municipality, 2) mean altitude of the municipality, 3) age ratio of the population, 4) proportion of farm owners $<34$ years old, and 5) the activity ratio. The surface of burned areas is higher in municipalities where the annual mean temperature is lower. As a general rule, fires are of greatest concern in forest and semi-natural areas. These covers dominate in mountain areas, i.e. in zones with a higher altitude. This is probably an indirect relationship. In mountains there are higher 
Figure 4

STATISTICAL MODEL SHOWING THE INDEPENDENT VARIABLES THAT INFLUENCE BURNED AREA COVER
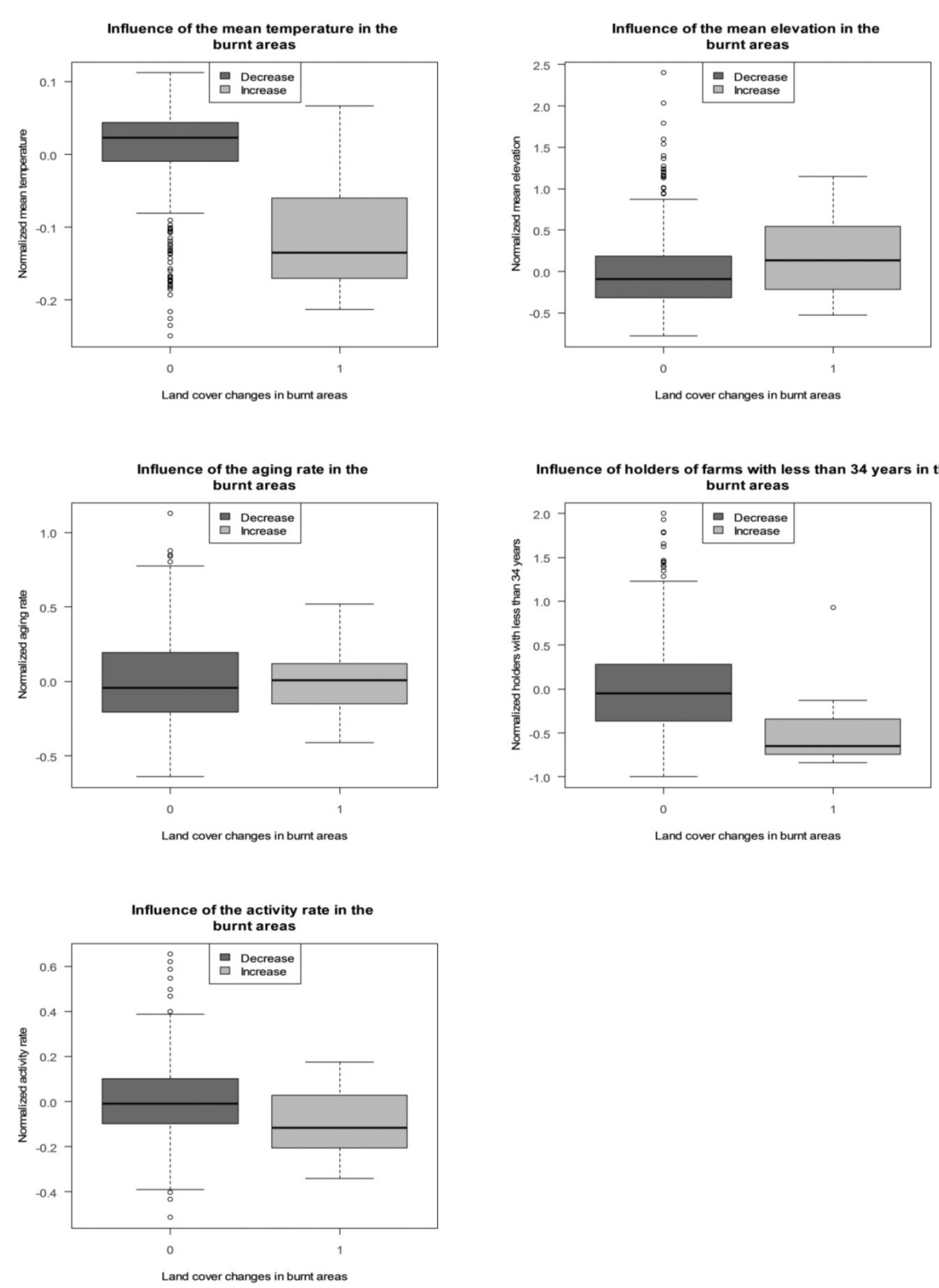

Sources: CORINE Land Cover - I\&CLC2000 Project - Spain (IGN, CNIG) and CORINE Land Cover I\&CLC2000 Project- Portugal (IA and IGP). The authors. 
Figure 5

STATISTICAL MODEL SHOWING THE INDEPENDENT VARIABLES THAT INFLUENCE VINEYARD COVER

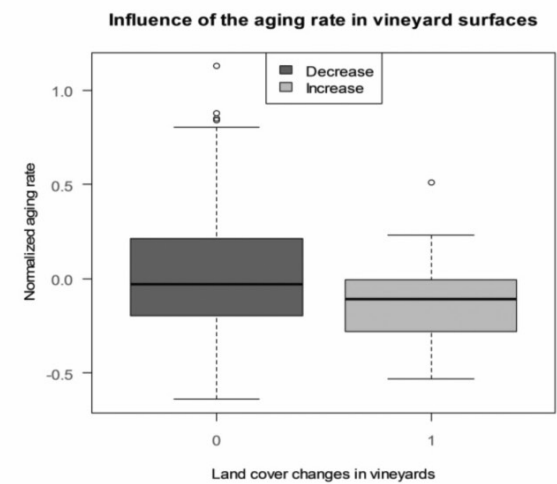

Influence of farms holders between 35-54 years in vineyard

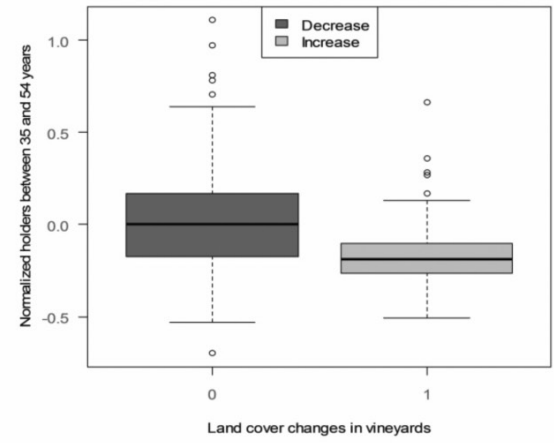

Influence of employees in agricul. sector in vineyard surfaces

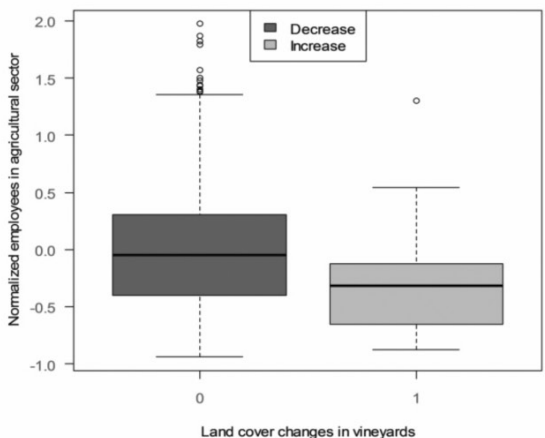

Influence of farms holders with less 34 years in vineyards

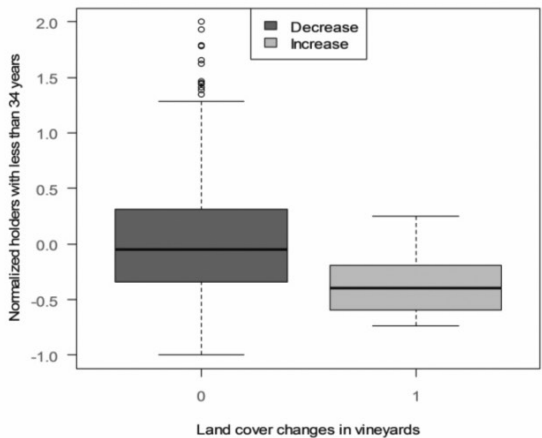

Influence of protected natural areas in vineyard surfaces
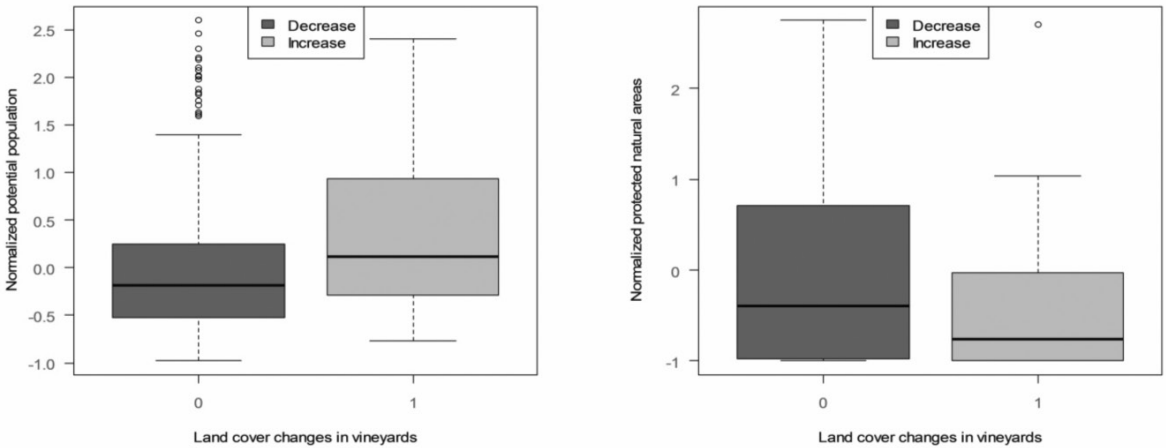

Sources: CORINE Land Cover - I\&CLC2000 Project - Spain (IGN, CNIG) and CORINE Land Cover I\&CLC2000 Project- Portugal (IA and IGP). The authors. 
slopes and soils are poorer. Therefore, the agrarian capacity is less and this increase forest surface, especially species of fast-growing (pine trees, eucalyptus). Consequently, the risk of fire in higher areas is greater. Municipalities with a higher population age ratio have lower numbers of people who can be employed in the agricultural sector. Thus, many previously cultivated lands are abandoned and invaded by shrubs and herbaceous vegetation that burns easily and spreads fires. The last two variables, farm owners $<34$ years old, and the activity ratio, are related to one another and to the independent variable, age ratio of the population. The lower the proportion of farm owners younger than 34 years and the lower the activity ratio, the higher the land surface area affected by fires.

The net change in surface cover of vineyards in the Raya Central Ibérica is highly significant. The statistical model showed several independent variables influence this land cover in the municipalities. In order of importance, they are: 1) age ratio of the population, 2) proportion of farm owners between the ages of 35 and 54,3) activity ratio, 4) proportion of the population in the agricultural sector, 5) proportion of farm owners $<34$ years old, 6) the proportion of the people living within 30 minutes of a population center, 7) density of goats, and 8) surface area of protected natural spaces.

The model shows that a lower age ratio of the population is associated with greater coverage by vineyards. Policies encourage the planting of new vine stocks, as well as mechanization and irrigation of vineyards. This has created a situation that favors young landholders, as older individuals lack the background to implement these new agricultural strategies. According to the logistic regression, land cover of vineyards increases in municipalities where the proportion of the population in the agricultural sector is lower. In municipalities where mechanization has been implemented, urban areas in many cases, a smaller work force is required, and this encourages viniculture. The municipalities with a positive net change in vineyards were some of the more densely populated urban areas in the study area. This explains the positive correlation between vineyard land cover and the proportion of people living within 30 minutes of a population center.

\section{DISCUSSION}

Land cover and land use changes have been detected and analyzed successfully at numerous sites around the world. Different modeling approaches have been used to identify land cover/land use changes and to determine the factors that drive these changes (Turner II et al., 1990). In many parts of the world, human activities are the primary drivers of land cover/land use changes, though the physical structure of the landscape can also influence the land cover and land use (Jongman, Bounce and Elena-Roselló, 1998). For example, soil conditions or steepness of slopes can make the cultivation of some cereals difficult. In any case, research into the dynamics of the land cover and land use requires an approach that integrates biophysical and human variables. For instance, despite the importance of physical characteristics, it is evident that socioeconomic factors play an important role in land use decisions. The most important driving factors in land cover and land use changes are land tenure, farm size, fragmentation of the plots, mechanization, and public policies. For example, with regard to land tenure, the family farms have the advantage that owners have legal authority to improve their farms. On the other hand, such changes may be too 
small to be economically beneficial. In relation to farm size and fragmentation of plots, large farms are generally considered to be more efficient. This may explain why in some regions dispersed parcels have been consolidated into a single large holding.

Future research on land cover/land use changes should explore how agrarian systems are influenced by the history of land possession. Among the topics that could be investigated are: 1) the inheritance system, 2) market pressures on land, 3) perception of the landscape, e.g. elements that farmers associate with local identity. All these themes should provide insights into the process land cover/land use change. Such studies will require contact with the farmers and extensive fieldwork. This requires that the spatial coverage of the study be limited to an appropriate area. Future work should also focus on improving our knowledge of dynamics in agrarian landscapes. Certain land uses are more inclined to fragment the landscape, whereas others tend to increase its homogeneity (Farina, 1998). An important characteristic of the traditional Mediterranean landscape is its rich ecological diversity (Faulkner and Hill, 1997), brought about, in part, by the fragmented land cover/land use (Folch and Paris, 1999). Thus, it is important to understand the impact on landscapes of land cover and land use changes.

Finally, it is necessary to mention that the results of the analyses illustrate the complex «behaviors» of the different covers on either side of the border. Much of this behavior can be attributed to the fact that each country has its own plans, programs, projects and policies (Marques, 1998; Palma, 1998; Coimbra, 2002; López, 2003; Pires, 2006; Beltrán, 2007; Campesino et al., 2008). For instance, whereas forest and semi-natural areas increased in Portuguese territory between 1990 and 2000, such land covers decreased in the provinces of Extremadura. In another example, the agro-forestry areas increased in coverage in Extremadura over the study period, this type of agricultural land use declined on the Portuguese side (Pinto-Correia, 2000; Regidor, 2006).

\section{CONCLUSIONS}

This study was designed to investigate land cover/land use changes in the Raya Central Ibérica (Spain and Portugal) between 1990 and 2000. It also explored the driving forces behind those land cover/land use changes. First, previous work was consulted to select potential independent variables that might explain land cover/land use changes in the region. Among them were socioeconomic, agricultural, accessibility and geophysical variables. Care was taken during selection of these independent variables to make sure they were not autocorrelated. Afterwards, appropriate techniques were chosen to conduct the analysis. Multiple logistic regressions, specifically the function $G L M$ of $R$, were used to determine the driving factors behind land cover/land use changes.

Almost $60 \%$ of the land cover changes in the Raya Central Ibérica were explained using the selected independent variables. Of fifteen dependent variables with minor variance, ten are agricultural land cover types. Land cover changes in the artificial, forest and water area categories, are explained by socioeconomic, agricultural, accessibility and physical variables.

The $g \operatorname{lm}()$ function of $R$ demonstrated its utility for identifying relations between independent variables and land cover/land use changes in the Raya Central Ibérica. High deviances obtained for many of the models, along with the fact that almost $60 \%$ of the 
changes in artificial, forest and water cover were explained, illustrate the utility of the statistical method. The selected independent variables, however, failed to explain about $40 \%$ of the change in land cover. This implies that we must seek additional potential explanatory variables, especially for agricultural land uses.

This study involved analysis of land use/land cover at several spatial scales: regional analysis (districts and provinces), sub-regional analysis (sub-regions) and municipal analysis (concelhos and municipalities). These analyses show that independent variables operating at multiple landscape scales give rise to the pattern of land cover and land use change seen throughout the transnational border territory.

The results of different analyses show that the changes have been insignificant in general terms, however, there are important variations between municipalities in some land cover and land uses such as irrigated land, agro-forestry areas or sclerophyllous vegetation.

Finally, we don't want to miss the opportunity to comment on that we know that the improvement of the quality of the analyzed data for any research should be a permanent goal. For studies of land cover and land use changes where CORINE data is used, the quality of the data item is essential as it determines such issues as environmental, territorial policies or sustainable development. On the other hand, it is also important to recognize that we know that spatial data are often difficult to assess in terms of quality as the study area is extensively spreading over national borders.

\section{ACKNOWLEDGEMENTS}

This study was supported by Spanish Department of Education. The authors are also grateful to the Department of Education for offering a FPU Scholarship 2006-03185, and the University of Extremadura for having facilitated the work. Of course, acknowledge the contribution of Dr. Brenner and UF too.

\section{REFERENCES}

BALABANIAN, O. (1984): «Problemas agricolas e reformas agrarias no Alto Alentejo e na Estremadura Espanhola» in PINTO-CORREIA, T. (2000). «Future development in Portuguese rural areas: how to manage agricultural support for landscape conservation?» Landscape and Urban Planning, $\mathrm{n}^{\circ}$ 50, 95-106.

BELTRÁN GARCÍA, S. (2007): «La Cooperación Transfronteriza e Interterritorial: un clásico renovado». REAF. Revista d'Estudis Autonómicos i Federals, n 4, 215-246.

BOR, W. VAN DEN, BRYDEN, J. M., AND FULLER, A. M. (1997): «Rethinking Rural Human Resource Management; the Impact of Globalisation and Rural Restructuring on Rural Education and Training in Western Europe» in TERLUIN, I. J. (2003) «Differences in economic development in rural regions of advanced countries: an overview and critical analysis of theories». Journal of Rural Studies, $\mathrm{n}^{\circ}$ 19, 327-344.

BROOK, B. W. AND BOWMAN, D. M. J. S. (2006): «Postcards from the past: charting the landscape-scale conversion of tropical Australian savanna to closed forest during the 20th century» in RESCIA, A. J., ET AL. (2008): «Reformulating the social-ecological system 
in a cultural rural mountain landscape in the Picos de Europa region (northern Spain)». Landscape and Urban Planning, $\mathrm{n}^{\circ} 88,23-33$.

CABERO DIÉGUEZ, V. (1997): «Portugal y España: una mirada geográfica a las relaciones ibéricas». Boletín de la Asociación de Geógrafos Españoles, n 25, 3-13.

CABERO DIÉGUEZ, V., CAMPESINO FERNÁNDEZ, A. J. AND LÓPEZ TRIGAL, L. (1995-1996): «Knowledge of border areas: the contribution of Spanish Geographers». Boletín de la Asociación de Geógrafos Españoles, n 21-22, 83-98.

CAMPESINO FERNÁNDEZ, A. J. (1997): «Alentejo-Extremadura: ciudades y ordenación del territorio». Boletín de la Asociación de Geógrafos Españoles, n ${ }^{\circ}$ 25, 67-82.

CAMPESINO FERNÁNDEZ, A. J. (2007): «Territorio y ciudades abaluartadas en la Raya / Raia ibérica: de frontera a Patrimonio Mundial en Serie» in CRUZ VILLALÓN, M. (COORD.) (2007): Ciudades y núcleos fortificados de la frontera hispano-lusa: el territorio de Extremadura y Alentejo. Historia y patrimonio. Universidad de Extremadura, Servicios de Publicaciones, 257-268.

CAMPESINO FERNÁNDEZ, A. J. (DIR.), SÁNCHEZ RIVERO, M. Y RENGIFO GALLEGO, J. I. (2008): «La Cooperación Transfronteriza Extremadura-AlentejoRegião Centro» in DOMÍNGUEZ CASTRO, L. (COORD.) (2008): A Cooperação Transfronteiriça entre Portugal e Espanha. Biblioteca de Estudos Estratégicos. Eixo Atlántico do Noroeste Peninsular. Vigo-Porto. IFDR, 235-262.

CAYUELA, L. (2009 a): Modelos lineales en R: Regresión, ANOVA y ANCOVA. Materiales del curso de R del IREC.

CAYUELA, L. (2009 b). Modelos lineales generalizados (GLM). Materiales de un curso del $\mathrm{R}$ del IREC.

CAYUELA, L. (2009 c): Una introducción a R. Material del curso de Doctorado de Análisis de Datos Ecológicos en R, Universidad de Alcalá.

CLOKE, P. J. (2003): «Country backwater to virtual village? Rural Studies and the cultural turn» in TERLUIN, I. J. (2003) «Differences in economic development in rural regions of advanced countries: an overview and critical analysis of theories». Journal of Rural Studies, $\mathrm{n}^{\circ} 19,327-344$.

COIMBRA, C. (2002): «Região Centro, Alentejo e Extremadura: Um estudo comparativo da região de fronteira». Revista de Estudos Regionais-Região Centro, $\mathrm{n}^{\circ} 1$.

CRAWLEY, M. J. (2005): Statistics. An introduction using R. Wiley.

CRAWLEY, M. J. (2007): The R Book. Wiley.

DE ARANZÁBAL, I., SCHMITZ, M. F., AGUILERA, P. AND PINEDA, F. D. (2008): «Modelling of landscape changes derived from the dynamics of socio-ecological systems. A case of study in a semiarid Mediterranean landscape». Ecological Indicators, n 8, 672 685.

DENDONCKER, N., ROUNSEVELL, M. AND BOGAERT, P. (2007): «Spatial analysis and modelling of land use distributions in Belgium. Computers». Environment and Urban Systems, $\mathrm{n}^{\circ} 31,188-205$.

FARINA, A. (1998): «Principles and methods in landscape ecology» in SERRA, P., ET AL. (2008): «Land-cover and land-use change in a Mediterranean landscape: A spatial analysis of driving forces integrating biophysical and human factors». Applied Geography, ${ }^{\circ}{ }^{2} 2$, 189-209. 
FLAMM, R. O. AND TURNER, M. G. (1994): «Alternative model formulations for a stochastic simulation of landscape change» in DE ARANZÁBAL, I., ET AL. (2008): «Modelling of landscape changes derived from the dynamics of socio-ecological systems. A case of study in a semiarid Mediterranean landscape». Ecological Indicators, n 8, 672 685.

FAULKNER, H. AND HILL, A. (1997): «Forests, soils and the threat of desertification» in SERRA, P., ET AL. (2008): «Land-cover and land-use change in a Mediterranean landscape: A spatial analysis of driving forces integrating biophysical and human factors». Applied Geography, n 28, 189-209.

FOLCH, R. AND PARIS, A. (1999). Environmental atlas of the Mediterranean in SERRA, P., ET AL. (2008): «Land-cover and land-use change in a Mediterranean landscape: A spatial analysis of driving forces integrating biophysical and human factors». Applied Geography, n 28, 189-209.

HIETEL, E., WALDHARDT, R. AND OTTE, A., (2004). «Analysing land-cover changes in relation to environmental variables in Hesse, Germany». Landscape Ecol., n ${ }^{\circ}$ 19, 473 489.

HIETEL, E., WALDHARDT, R. AND OTTE, A. (2005): «Linking socio-economic factors, environment and land cover in the German Highlands, 1945-1999». Journal of Environmental Management, $\mathrm{n}^{\mathrm{o}}$ 75, 133-143.

HILLIER, J. (1998): «Paradise proclaimed? Towards a theoretical understanding of representations of nature in land-use planning decision-making» in HURLEY, P. T. AND WALKER, P. A. (2004): «Whose vision? Conspiracy theory and land-use planning in Nevada County, California». Environment and Planning A, $\mathrm{n}^{\circ} 36,1529-1547$.

HURLEY, P. T. AND WALKER, P. A. (2004): "Whose vision? Conspiracy theory and landuse planning in Nevada County, California». Environment and Planning A, $\mathrm{n}^{\circ} 36,1529$ 1547.

IRWIN, E. G. AND GEOGHEGAN, J. (2001): «Theory, data, methods: developing spatially explicit economic models of land use change». Agriculture, Ecosystems and Environment, $\mathrm{n}^{\mathrm{o}} 85,7-23$.

JARAÍZ, F. J. (2011): Nuevas dinámicas territoriales y sus repercusiones sobre los cambios de uso del suelo en la Raya Central Ibérica. Directores: Julián Mora Aliseda y José Antonio Gutiérrez Gallego. Universidad de Extremadura, Departamento de Ciencias del Territorio. Pendiente de publicación.

JOFFRE, R., HUBERT, B., MEURET, M. (1991): «Les systeemes agro-silvopastoraux mediterraneens: enjeux et reaexions pour une gestion raisonee» in PINTO-CORREIA, T. (2000). «Future development in Portuguese rural areas: how to manage agricultural support for landscape conservation?» Landscape and Urban Planning, $\mathrm{n}^{\circ}$ 50, 95-106.

JONGMAN, R. H., BUNCE, R. G. AND ELENA-ROSSELLO, R. (1998): «A European perspective on the definition of landscape character and biodiversity. Key concepts in landscape ecology» in SERRA, P., ET AL. (2008): «Land-cover and land-use change in a Mediterranean landscape: A spatial analysis of driving forces integrating biophysical and human factors». Applied Geography, n 28, 189-209.

LACITIGNOlA, D., PETROSILlO, I., CATAlDI, M. AND ZURLINI, G. (2007): «Modelling socio-ecological tourism-based systems for sustainability» in DE 
ARANZÁBAL, I., ET AL. (2008): «Modelling of landscape changes derived from the dynamics of socio-ecological systems. A case of study in a semiarid Mediterranean landscape». Ecological Indicators, $\mathrm{n}^{\circ}$ 8, 672-685.

LE SAGE, J. P. AND KELLEY, R. (2009): Introduction to Spatial Econometrics. Boca Raton, London, New York. CRC Press Taylor \& Francis Group.

LÓPEZ TRIGAL, L. (2003): «La Raya Ibérica como espacio de atracción y cooperación» in Papeles de Economía Española. Economía de las Comunidades Autónomas, no 21, 3-13.

LÓPEZ TRIGAL, L., LOIS GONZÁLEZ, R. AND GUICHARD, F. (1997). La articulación territorial de la raya hispanoportuguesa. Actas Simposium Vilar Formoso. Zamora. Fundación Rei Afonso Henriques.

LORENZONI, I., JORDAN, A. HULME, M., TURNER, R. K. AND RIORDAN, T. (2000): «A co-evolutionary approach to climate change impact assessment: Part I Integrating socio-economic and climate change scenarios» in DE ARANZÁBAL, I., ET AL. (2008): «Modelling of landscape changes derived from the dynamics of socio-ecological systems. A case of study in a semiarid Mediterranean landscape». Ecological Indicators, $\mathrm{n}^{\circ}$ 8, 672 685.

KRISTENSEN, L. S., THENAIL, C. AND KRISTENSEN, S. P. (2004): «Landscape changes in agrarian landscapes in the 1990s: the interaction between farmers and the farmed landscape. A case study from Jutland, Denmark» in VERBURG, P. H., ET AL. (2006): «Downscaling of land use change scenarios to assess the dynamics of European landscapes». Agriculture, Ecosystems and Environment, $\mathrm{n}^{\circ}$ 114, 39-56.

MACFARLANE, R. (1998): «Implementing agri-environment policy: a landscape ecology perspective» in PINTO-CORREIA, T. (2000): «Future development in Portuguese rural areas: how to manage agricultural support for landscape conservation?». Landscape and Urban Planning, $\mathrm{n}^{\circ}$ 50, 95-106.

MARQUES REIGADO, F. (1998): «Estrategias, dificultades y potencialidades de desarrollo regional transfronterizo: El caso particular de Extremadura y del Alentejo y Beira Interior». Cuadernos Monográficos de Urbanismo y Ordenación del Territorio, $\mathrm{n}^{\circ} 1$, 81-85.

MATTHEWS, R. (2006): «The People and Landscape Model (PALM): towards full integration of human decision-making and biophysical simulation models» in DE ARANZÁBAL, I., ET AL. (2008): «Modelling of landscape changes derived from the dynamics of socio-ecological systems. A case of study in a semiarid Mediterranean landscape». Ecological Indicators, $\mathrm{n}^{\circ}$ 8, 672-685.

MILlingtON, J. D. A., PERRY, G. L. W. AND ROMERO-CALCERRADA, R. (2007): «Regression Techniques for Examining Land Use/Cover Change: A Case Study of a Mediterranean Landscape». Ecosystems, nº 10, 562-578.

MORA, J. (1997): Los ríos internacionales Tajo y Guadiana en el desarrollo integral de Extremadura, Alentejo y Beira Interior. Cáceres. Gabinete de Iniciativas Transfronterizas, Junta de Extremadura, Centro Europeo de Desarrollo Regional.

OBSERVATORIO DE LA SOSTENIBILIDAD EN ESPAÑA (2006): Cambios de ocupación del suelo en España: Implicaciones para la sostenibilidad. Madrid. Mundi-Prensa Libros, $485 \mathrm{p}$. 
PALMA, F. (1998): «Definición y gestión de las redes de espacios naturales en la subregión Alentejo. Articulación en el continuo geográfico». Cuadernos Monográficos de Urbanismo y Ordenación del Territorio, $\mathrm{n}^{\circ}$ 1, 15-22.

PINTO-CORREIA, T. (2000). «Future development in Portuguese rural areas: how to manage agricultural support for landscape conservation?». Landscape and Urban Planning, $\mathrm{n}^{\circ}$ 50, 95-106.

PIRES, I. (Coord.). 2006: As relações entre Portugal e Espanha: oportunidades criadas no contexto europeu. Lisboa. Ed. Universidade de Lisboa.

RESCIA, A. J. (2008): «Reformulation the social-ecological system in a cultural rural mountain landscape in the Picos de Europa region (northern Spain)». Landscape and Urban Planning, $\mathrm{n}^{\mathrm{o}} 88,23-33$.

REGIDOR J. G. (2006): Desarrollo rural de base territorial: Extremadura (España). Badajoz. Consejería de Desarrollo Rural y Ministerio de Agricultura, Pesca y Alimentación, 283 p.

ROMERO-CALCERRADA, R. AND PERRY, G. L. W. (2004): «The role of land abandonment in landscape dynamics in the SPA Encinares del río Alberche y Cofio, Central Spain, 1984-1999» in RESCIA, A. J. (2008): «Reformulating the socialecological system in a cultural rural mountain landscape in the Picos de Europa region (northern Spain)». Landscape and Urban Planning, $\mathrm{n}^{\circ}$ 88, 23-33.

ROUNSEVELL, M. D. A., EWERT, F., REGINSTER, I., LEEMANS, R. AND CARTER, T. R. (2005): «Future scenarios of European agricultural land use: II. Projecting changes in cropland and grassland» in VERBURG, P. H., ET AL. (2006): «Downscaling of land use change scenarios to assess the dynamics of European landscapes». Agriculture, Ecosystems and Environment, $\mathrm{n}^{\circ} 114,39-56$.

SCHMITZ, M. F., DE ARANZABAL, I., AGUILERA, P., RESCIA, A. AND PINEDA, F. D. (2003): «Relationschip between landscape typology and socieconomic structure: Scenarios of changes in Spanish cultural landscapes». Ecological Modelling, ${ }^{\circ} 168$, 343-356.

SERRA, P., PONS, X. AND SAURÍ, D. (2008): «Land-cover and land-use change in a Mediterranean landscape: A spatial analysis of driving forces integrating biophysical and human factors». Applied Geography, n 28, 189-209.

TERLUIN, I. J. (2003) «Differences in economic development in rural regions of advanced countries: an overview and critical analysis of theories». Journal of Rural Studies, $\mathrm{n}^{\circ} 19$, 327-344.

TURNER, B. L., II, CLARK, W. C., KATES, R., RICHARDS, J., MATHEWS, J. T. AND MEYER, W. B. (1990): The Earth as transformed by human action in SERRA, P., ET AL. (2008): «Land-cover and land-use change in a Mediterranean landscape: A spatial analysis of driving forces integrating biophysical and human factors». Applied Geography, $\mathrm{n}^{\circ}$ 28, 189-209.

VERBURG, P. H., SCHUlP, C. J. E., WITTE, N. AND VELDKAMP, A. (2006): «Downscaling of land use change scenarios to assess the dynamics of European landscapes». Agriculture, Ecosystems and Environment, $\mathrm{n}^{\circ} 114,39-56$.

WANG, Y. AND ZHANG, X. (2001): «A dynamic modeling approach to simulating socioeconomic effects on landscape changes» in DE ARANZÁBAL, I., ET AL. (2008): 
«Modelling of landscape changes derived from the dynamics of socio-ecological systems. A case of study in a semiarid Mediterranean landscape». Ecological Indicators, n 8, 672 685.

WHATMORE, S. AND BOUCHER, S. (1993): «Bargaining with nature: the discourse and practice of environmental gain» in HURLEY, P. T. AND WALKER, P. A. (2004): «Whose vision? Conspiracy theory and land-use planning in Nevada County, California». Environment and Planning A, $\mathrm{n}^{\circ}$ 36, 1529-1547.

WU, J. AND HOBBS, R. (2002): «Key issues and research priorities in landscape ecology: an idiosyncratic synthesis» in DE ARANZÁBAL, I., ET AL. (2008): «Modelling of landscape changes derived from the dynamics of socio-ecological systems. A case of study in a semiarid Mediterranean landscape». Ecological Indicators, no 8, 672-685. 